\title{
Using SWOT analysis for defining strategies of mobile learning
}

\author{
Matija Grčić \\ Department of Special Programs Development \\ University of Zagreb, University Computing Centre Srce \\ Zagreb, Croatia \\ matija.grcic@srce.hr
}

\author{
Ruben Picek \\ Department of Information System Development \\ University of Zagreb, Faculty of Organization and \\ Informatics \\ Varaždin, Croatia \\ ruben.picek@foi.hr
}

Received: March 5, 20.21. Revised: Novemeber 6, 2021. Accepted: December 22, 2021. Published: January 7, 2022.

\begin{abstract}
After exploring the concept of m-learning, this paper focuses on defining a SWOT analysis of mobile learning with detail discussion of each element. Finding important relationships by matching well know SWOT variables in a systematic fashion is a next step of research where using a algorithm which can provide a help in defining appropriate strategy. The result of our research is a conceptual framework for defining strategies for mobile learning, which will help primarily universities or other educational institutions in estimating their own position and creating the strategy for adopting m-learning into their curriculums which make a valuable contribution for the future research in this area.
\end{abstract}

Keywords-mobile learning; SWOT analysis; SWOT rang; activities; goals; defensive; aggressive; strategy for adopting mlearning

\section{INTRODUCTION}

One aspect of using mobile technologies is learning, so a new acronym known as mobile learning (m-learning) is entering to our society. Spare time of some person can be constructively used that otherwise would be wasted. For example, when travelling or waiting in queue person could use its mobile device to learn some piece of interest [4]. All this creates a new opportunities in communication including education. Mobile learning is undoubtedly a new way of teaching and learning, worthy of detail study.

Despite of constant development of mobile technology and increasing availability of wireless mobile devices, adopting mobile learning is disappointingly slow. Recent research, conducted by authors, at Croatian university confirms that students are not ready to become a "mobile learner" [5]. Reasons for that can be founded in technology or learner profiles but one potential reason can also be a lack of mobile learning strategies. Need for mobile learning strategies are evident but the question is how to define it. This article seeks to provide a comprehensive SWOT analysis for strategies definition of mobile learning and attempts to understand why actual learning practices are changing very rapidly while the learning environments that support educational practices are not. To find viable answers, the article will provide the activities and goals needed to adopt mobile learning and the increasing mobility of learners, learning and learner technology.

\section{Mobile LeARning as Potential EduCATIONAL ENVIRONMENT}

Technological advances have made mobile learning a reality and it will greatly influence the modern way of learning. Mobile learning evolves from the needs of flexible and ubiquitous learning and its aim is to enable a flexible learning environment that everyone can learn anywhere, anytime and on any (mobile) device. Mobile devices not only enable anytime anywhere communication, but they have also extended their capabilities to help users consume and generate a broad range of different kinds of media, which, consequently, has dramatically increased the social significance of these devices.

The key idea of that concept is to support the educational process to provide auxiliary access to educational information sources, such as announcements, course schedules, grades, and user directory details. Future steps include multimedia messages (MMS) integration and third-generation (3G)-based information delivery and multimedia streaming [1].

In other words, mobile learning is the intersection of mobile computing and e-learning that includes flexible resources, strong search capabilities, rich interaction and powerful support for effective learning [2]. For a long time, there has been a clear trend of convergence for mobile device features. These small and ubiquitous devices could be an excellent opportunity to turn young people's love of mobile gadgets from what could become a waste of time into a motivational tool that could foster their interest in learning [6].

\section{SWOT ANALYSIS OF MOBILE LEARNING}

This section presents a detail analysis of mobile learning in the context of strengths (S), weaknesses (W), opportunities (O) and threats $(\mathrm{T})$ by using well known method SWOT analysis which has long been acknowledged in many industries and educational fields as a useful analytical tool for building strategies [9]. 


\section{A. Strengths of mobile learning}

Mobile learning relies on the present wireless mobile networks, internet and multimedia technology and of course mobile devices like PDAs, smart phones and tablets which are used more and more for wide spectrum of our each day activities - from personal interaction to social networking, from grocery shopping to banking, from popular culture to politics. Author Kurkovsky names that growing influence with the term "mobile culture" [6]. Mobile learning is everywhere, is easy to use, and has rich content, high efficiency, flexibility, security, reliability, interactivity, portability and other features that can be used to compete with the other language teaching methods. Mobile learning has brought us new ideas, and with the $3 \mathrm{G}$ technology, the global mobile learning is possible [7]. Mobile learning is a digital learning. Learning resources include: digital text, graphics, images, videos and audio files which are easy to copy, transport and store. A learner is not fixed in front of a computer desk any more. Mobile learning allows him to study small modules and tasks at their own convenience, to be an entirely active and choose what and how much to study in their own time. M-learning has the ability to be widespread and completely personalized allowing the learner to choose their subject matter, time and location of study [7].

So the first benefit is highly independent way of learning, enabling learner to carry course material around in a small lightweight device [4]. The second is a worldwide information access and safety information delivery. Composing, sending, and receiving e-mail, writing documents, browsing the Internet, accessing multimedia objects, accessing learning management systems and using synchronous communications tools are nowadays reality. The significant role for that has the availability of wireless networks. It is likely that as wireless networks will become more widespread, devices will become more fully functional, enabling in that way more efficient way of information access, social interaction and networking. It is evident correlation between technology progress and use of devices for m-learning. The third strength is, that today's mobile devices are practical, affordable and available to enable mobile learning. With each new wave of phones and tablets (about every three months), we are introduced to technology that is bigger, stronger, faster with increasing memory and storage capacity making it possible for complex applications to reside on devices. The fourth strength of mobile learning is the platform itself.

The platform is easy to use from a development standpoint. The format is open and does not involve most of the complicated characteristics of a desktop system. The fifth strength is that internet connectivity on phones is not restricted to WiFi alone. Options like EDGE, $3 \mathrm{G}, 4 \mathrm{G}$ and even WAP exist. SMS and voice can also be used for learning tools on mobile. Finally, adaptable learning strategies, tools and resources can be adjusted to learner's profile. For example, one of profile can be learners with special needs or learning disabilities.

\section{B. Weaknesses of Mobile Learning}

Mobile learning is constrained by mobile device characteristics as much as it is enabled by them. For many, the term mobile learning often evokes images of cellular telephones with tiny screens and limited options. Others imagine tiny and mid size touch screen for normally reading. Size of device, battery life, usability and cost are main disadvantages of mobile devices used for m-learning. Ultimately, the degree of constraint or comfort is dependent upon the hardware and software configurations.

The second weakness is numerous operating platforms, device types and variations in supported technologies that make it difficult (and at times impractical) to create a unified solution which works well across the platforms.

However, one more criticism in a mobile education is that learners receive impersonal teaching. Solution for this problem is given in [1] providing affective interaction based on user's emotional state. They describe bi-modal educational system for mobile device based on two modalities; the keyboard and the microphone through a multi criteria decision making theory. While the development platforms and tools are easy-to-use, using such tools to design effective learning solutions is another matter altogether. It requires a skill-set that includes instructional and media design competencies for mobile device, and interface \& user experience design skills. Related problem is a lack of tools to create engaging mobile learning content. All that can be seen as a third weakness. Concerns around basic device security and data security with lack of common standards for mobiles can be observed as fourth weakness. And last, technology does not guarantee better learning, but it does provide learners a solid grounding in their chosen subject matter, as well as all the teaching and learning resources of traditional learning.

\section{Opportunities of mobile learning}

Mobile devices have a power to become extensions of media distribution in all segments. On any mobile device, the user experience will be different than on a desktop or laptop due to a smaller screen size and touch navigation so the question is can this limitation be taken into account? Providing highly intuitive user experience to reduce the number of actions user needs to perform is what authors propose as learners should focus on their activities not on technology [10]. Learning materials can be stored in a number of places therefore a need for a better content organization is needed. Providing fast access to books, student or lecturer notes, and tutorials is one of the recognized opportunities. Mobile learning can provide real-time learning improvements based on demand. For many students a lack of impersonal teaching can be replaced having information on demand, at their fingertips, because that is the way they work.

One issue that became clear is that mobile learning is not just about learning using portable devices. With technology getting smaller, more personal, ubiquitous, and powerful it is crucial to better support a mobile society. Authors defined social integration as an opportunity to learn across different contexts because mobile learning is not something that people do; learning is what people do. Today's mobile computing devices have more power than the largest computers of a generation ago, and this trend continues. New protocols for better, faster data transfer are emerging and they will be 
implemented to overcome this restriction. Choosing the right protocol is a new opportunity.

\section{Threats of mobile learning}

Because of such diversity of mobile devices, complex architecture is necessary and hard to overcome. Supporting multiple platforms and different technical frameworks is hard, time consuming and expensive process.

Knowing which devices, operating systems, and networks will have the longest life has seemed difficult to predict. Recently some favorites have emerged, but there is still substantial turbulence in the mobile market, especially with the advent of various tablet devices. In previous sections authors defined content organization as an opportunity but it can be viewed as a threat also. Big data is currently one of highly discussed topic. Sorting, storing, locating all the right information is not an easy task but if done properly it provides higher user satisfaction. There are no standards that define what mobile really should be although several guidelines, learning practices and articles are written on this subject.

Since mobile education and training is a very young discipline, there are no generally recognized standards in this area. Usually, it's possible to use general standards and standards for e-learning, adapted to m-learning, respecting all advantages and limitations of mobile devices. Related to the training model, the most appropriate model would be one given in ISO 10015:1999 standard - Quality Management - Guidelines for Training [8].

Technology can be addictive and the user can abuse it. When designing mobile learning environments we should be very careful not to overwhelm our users as it can become an unwanted and serious problem instead of a rich feature. Instead user will focus greatly on the technology rather on the learning as a process which ultimately becomes a distraction. To produce non distraction mobile learning model, there is a need to work closely with classroom teachers to make their lessons so interesting that students don't feel the need to wander. Given that students can wander with or without technology, teachers are still responsible for managing the learning process.

Cheating temptation is arguably even greater with mobile learning than with traditional learning though, because of the portability of the devices it is easy to pass assignments to someone else who will do the assessment. Adopting new technology is a barrier in every field not only in mobile learning. Fear of technology, or complete ignorance of its existence, has frightened away many prospective educators, thus robbing students of the opportunity to learn from not only listening to, but creating these podcasts. This will certainly change as more and more educators become aware of the software's simplicity and ease of use. The last threat that authors identified is a process of depletion of face to face interaction.
Physical and cognitive factors have great impact on the performance of distance education learners while using mobile learning technologies and this is a field that has yet to be adequately explored and investigated [11].

\section{E. SWOT elements}

Before proceeding to the next step, defining SWOT matrix, author's provided a summary of SWOT elements described in previous sections which are shown in Table 1.

TABLE I. SWOT Elements

\begin{tabular}{|c|c|c|c|c|c|c|c|}
\hline \multicolumn{8}{|c|}{ SWOT ELEMENTS } \\
\hline S1 & $\begin{array}{l}\text { Independent } \\
\text { way } \\
\text { of learning }\end{array}$ & W1 & $\begin{array}{l}\text { Learning } \\
\text { experience is } \\
\text { constrained } \\
\text { by mobile } \\
\text { device } \\
\text { characteristics }\end{array}$ & O1 & $\begin{array}{l}\text { Mobile } \\
\text { devices as an } \\
\text { extensions of } \\
\text { media } \\
\text { distribution in } \\
\text { all segments }\end{array}$ & $\mathrm{T} 1$ & $\begin{array}{l}\text { Complex } \\
\text { architecture } \\
\text { (multiple } \\
\text { platforms } \\
\text { and } \\
\text { different } \\
\text { technical } \\
\text { frameworks) }\end{array}$ \\
\hline $\mathrm{S} 2$ & $\begin{array}{l}\text { Worldwide } \\
\text { information } \\
\text { access and } \\
\text { safety } \\
\text { information } \\
\text { delivery }\end{array}$ & W2 & $\begin{array}{l}\text { No unified } \\
\text { solution } \\
\text { across all the } \\
\text { platforms. }\end{array}$ & $\mathrm{O} 2$ & $\begin{array}{l}\text { Highly } \\
\text { intuitive user } \\
\text { experience } \\
\text { (reduced } \\
\text { number of } \\
\text { actions) }\end{array}$ & $\mathrm{T} 2$ & $\begin{array}{l}\text { Big data } \\
\text { (sort, store, } \\
\text { locate } \\
\text { information) }\end{array}$ \\
\hline S3 & $\begin{array}{l}\text { Practical, } \\
\text { affordable } \\
\text { mobile } \\
\text { ready } \\
\text { devices }\end{array}$ & W3 & $\begin{array}{l}\text { Impersonal } \\
\text { teaching }\end{array}$ & O3 & $\begin{array}{l}\text { Better content } \\
\text { organization }\end{array}$ & T3 & $\begin{array}{l}\text { Lack of } \\
\text { standards } \\
\text { for learning } \\
\text { on mobile }\end{array}$ \\
\hline S4 & $\begin{array}{l}\text { Open } \\
\text { platform }\end{array}$ & W4 & $\begin{array}{l}\text { Lack of tools } \\
\text { for authoring } \\
\text { learning } \\
\text { content }\end{array}$ & $\mathrm{O} 4$ & $\begin{array}{l}\text { Real-time } \\
\text { learning } \\
\text { improvements } \\
\text { based on } \\
\text { demand }\end{array}$ & $\mathrm{T} 4$ & $\begin{array}{l}\text { Prolonged } \\
\text { use } \\
\text { (abusing, } \\
\text { too much } \\
\text { technology } \\
\text { can be } \\
\text { dangerous) }\end{array}$ \\
\hline S5 & $\begin{array}{l}\text { Various } \\
\text { ways to } \\
\text { achieve } \\
\text { internet } \\
\text { connectivity }\end{array}$ & W5 & $\begin{array}{l}\text { Device and } \\
\text { data security }\end{array}$ & O5 & $\begin{array}{l}\text { Improved } \\
\text { flexibility and } \\
\text { portability }\end{array}$ & T5 & $\begin{array}{l}\text { Distraction } \\
\text { within the } \\
\text { learning } \\
\text { environment } \\
\text { (focus on } \\
\text { technology } \\
\text { rather on } \\
\text { learning } \\
\text { methods) }\end{array}$ \\
\hline \multirow[t]{3}{*}{ S6 } & $\begin{array}{l}\text { Resources } \\
\text { and } \\
\text { materials } \\
\text { can be } \\
\text { adjusted to } \\
\text { learner's } \\
\text { profile }\end{array}$ & W6 & $\begin{array}{l}\text { Unchartered } \\
\text { industry }\end{array}$ & O6 & $\begin{array}{l}\text { Faster and } \\
\text { smaller data } \\
\text { transfer } \\
\text { (protocols) }\end{array}$ & T6 & $\begin{array}{l}\text { New } \\
\text { cheating } \\
\text { mechanisms }\end{array}$ \\
\hline & & W7 & $\begin{array}{l}\text { Expensive to } \\
\text { implement }\end{array}$ & 07 & $\begin{array}{l}\text { Social } \\
\text { integration }\end{array}$ & $\mathrm{T} 7$ & $\begin{array}{l}\text { Technology } \\
\text { adoption } \\
\text { barrier }\end{array}$ \\
\hline & & & & & & $\mathrm{T} 8$ & $\begin{array}{l}\text { Depletion of } \\
\text { face to face } \\
\text { interaction }\end{array}$ \\
\hline
\end{tabular}




\section{F. SWOT matrix}

Defining SWOT matrix is a process of evaluating and comparing strengths, weaknesses, opportunities and threats and the result of this process is a matrix shown in Tables 2 to 5 . To further explain the results and the used algorithm authors will use Table 1. Indentifying six strengths (S1 to S6) it is necessary to draw a table with numbers of fields to do the comparing process. Number of fields is defined by a formula shown in Fig. 1.

$$
\frac{n \cdot(n-1)}{2}
$$

Fig. 1. Formula for calculating the number of fields

If there is n number of strengths then the formula is defined as shown in Fig 2.

$$
\left(\begin{array}{l}
n \\
3
\end{array}\right)=\frac{n !}{(n-3) ! \cdot 3 !}
$$

Fig. 2 Formula for calculating the $\mathrm{n}$ number of fields

When comparing strengths transitive dependency must be maintained. Transitive dependency is a functional dependency which holds by virtue of transitivity. It is important to know that a transitive dependency can occur only in a relation that has three or more attributes.

TABLE II. STRENGTHS MATRIX

\begin{tabular}{|c|c|c|c|c|c|c|}
\hline & S1 & S2 & S3 & S4 & S5 & S6 \\
\hline S1 & X & S1 & S1 & S1 & S1 & S1 \\
\hline S2 & X & X & S2 & S2 & S2 & S1 \\
\hline S3 & X & X & X & S4 & S3 & S6 \\
\hline S4 & X & X & X & X & S4 & S6 \\
\hline S5 & X & X & X & X & X & S6 \\
\hline S6 & X & X & X & X & X & X \\
\hline
\end{tabular}

TABLE III. WEAKNESSES MATRIX

\begin{tabular}{|c|c|c|c|c|c|c|c|}
\hline & W1 & W2 & W3 & W4 & W5 & W6 & W7 \\
\hline W1 & X & W1 & W3 & W1 & W5 & W1 & W1 \\
\hline W2 & X & X & W3 & W3 & W5 & W2 & W2 \\
\hline W3 & X & X & X & W2 & W5 & W3 & W3 \\
\hline W4 & X & X & X & X & W4 & W6 & W7 \\
\hline W5 & X & X & X & X & X & W5 & W5 \\
\hline W6 & X & X & X & X & X & X & W7 \\
\hline W7 & $\mathrm{X}$ & $\mathrm{X}$ & $\mathrm{X}$ & $\mathrm{X}$ & $\mathrm{X}$ & $\mathrm{X}$ & X \\
\hline
\end{tabular}

TABLE IV. OPPORTUNITIES MATRIX

\begin{tabular}{|c|c|c|c|c|c|c|c|}
\hline & O1 & O2 & O3 & O4 & O5 & O6 & O7 \\
\hline O1 & X & O1 & O1 & O1 & O1 & O1 & O1 \\
\hline O2 & X & X & O3 & O2 & O5 & O2 & O2 \\
\hline O3 & X & X & X & O3 & O5 & O6 & O3 \\
\hline O4 & X & X & X & X & O5 & O6 & O4 \\
\hline O5 & X & X & X & X & X & O6 & O6 \\
\hline O6 & X & X & X & X & X & X & O6 \\
\hline O7 & X & X & X & X & X & X & X \\
\hline
\end{tabular}

TABLE V. THREATS MATRIX

\begin{tabular}{|c|c|c|c|c|c|c|c|c|}
\hline & $\mathrm{T} 1$ & $\mathrm{~T} 2$ & $\mathrm{~T} 3$ & $\mathrm{~T} 4$ & $\mathrm{~T} 5$ & $\mathrm{~T} 6$ & $\mathrm{~T} 7$ & $\mathrm{~T} 8$ \\
\hline $\mathrm{T} 1$ & $\mathrm{X}$ & $\mathrm{T} 1$ & $\mathrm{~T} 3$ & $\mathrm{~T} 1$ & $\mathrm{~T} 1$ & $\mathrm{~T} 1$ & $\mathrm{~T} 7$ & $\mathrm{~T} 1$ \\
\hline $\mathrm{T} 2$ & $\mathrm{X}$ & $\mathrm{X}$ & $\mathrm{T} 3$ & $\mathrm{~T} 2$ & $\mathrm{~T} 2$ & $\mathrm{~T} 2$ & $\mathrm{~T} 7$ & $\mathrm{~T} 2$ \\
\hline $\mathrm{T} 3$ & $\mathrm{X}$ & $\mathrm{X}$ & $\mathrm{X}$ & $\mathrm{T} 3$ & $\mathrm{~T} 3$ & $\mathrm{~T} 3$ & $\mathrm{~T} 7$ & $\mathrm{~T} 3$ \\
\hline $\mathrm{T} 4$ & $\mathrm{X}$ & $\mathrm{X}$ & $\mathrm{X}$ & $\mathrm{X}$ & $\mathrm{T} 5$ & $\mathrm{~T} 4$ & $\mathrm{~T} 7$ & $\mathrm{~T} 4$ \\
\hline $\mathrm{T} 5$ & $\mathrm{X}$ & $\mathrm{X}$ & $\mathrm{X}$ & $\mathrm{X}$ & $\mathrm{X}$ & $\mathrm{T} 6$ & $\mathrm{~T} 7$ & $\mathrm{~T} 5$ \\
\hline $\mathrm{T} 6$ & $\mathrm{X}$ & $\mathrm{X}$ & $\mathrm{X}$ & $\mathrm{X}$ & $\mathrm{X}$ & $\mathrm{X}$ & $\mathrm{T} 7$ & $\mathrm{~T} 6$ \\
\hline $\mathrm{T} 7$ & $\mathrm{X}$ & $\mathrm{X}$ & $\mathrm{X}$ & $\mathrm{X}$ & $\mathrm{X}$ & $\mathrm{X}$ & $\mathrm{X}$ & $\mathrm{T} 7$ \\
\hline $\mathrm{T} 8$ & $\mathrm{X}$ & $\mathrm{X}$ & $\mathrm{X}$ & $\mathrm{X}$ & $\mathrm{X}$ & $\mathrm{X}$ & $\mathrm{X}$ & $\mathrm{X}$ \\
\hline
\end{tabular}

\section{G. SWOT rang}

SWOT rang is calculated by counting the number of occurrences of strengths, weaknesses, opportunities and threats in the corresponding tables shown in previous section. SWOT rang is shown in Table 6. The purpose of SWOT rang is to eliminate SWOT elements that have no real value so that strategies can be defined properly.

TABLE VI. SWOT Rang
\begin{tabular}{|c|c|c|c|}
\hline \multicolumn{4}{|c|}{ SWOT Rang } \\
\hline S1 & W5 & O1 & T3 \\
\hline S2 & W1 & O6 & T7 \\
\hline S6 & W3 & O2 & T1 \\
\hline S4 & W2 & O5 & T2 \\
\hline S3 & W7 & O3 & T4 \\
\hline & W4 & O4 & T5 \\
\hline & W6 & & T6 \\
\hline
\end{tabular}

\section{Defining STRATEgIES}

After SWOT rang is calculated the process of defining strategies is started. This process serves as a conceptual framework for future research about the combination of SWOT elements and their value. Equally important, the previously defined matrixes help to develop strategies, actions and goals [3]. 


\section{A. Corrective Strategies}

Corrective strategies are identified when evaluating strength with weakness $(\mathrm{S}, \mathrm{W})$, opportunity with threat $(\mathrm{O}, \mathrm{T})$, strength with threat $(\mathrm{S}, \mathrm{T})$ and opportunity with weakness $(\mathrm{O}, \mathrm{W})$. Authors identified seven corrective strategies which are shown in Table 7.

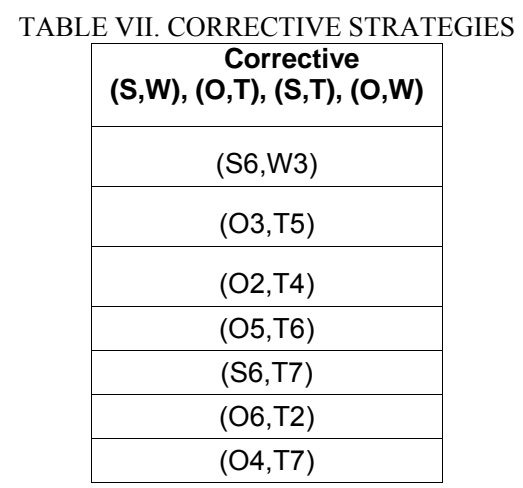

First corrective strategy identified is (S6,W3) which purpose is to correct the weakness of impersonal teaching by adjusting resources and materials to learner's profile. $(\mathrm{O} 3, \mathrm{~T} 5)$ strategy is identified to correct the distraction that learner has within the learning environment by focusing on technology rather than on learning materials. Prolonged use of technology can be dangerous therefore implementing highly intuitive user experience which will reduced user actions is third corrective strategy $(\mathrm{O} 2, \mathrm{~T} 4)$. Improving flexibility and portability will be used to defend mobile learning systems against cheating $(\mathrm{O} 5, \mathrm{~T} 6)$. Strength of adjusting to learners profile will be used to overcome technology adoption barrier which is the second most important threat in the new SWOT rang (S6,T7). Sixth identified strategy $(\mathrm{O} 6, \mathrm{~T} 2)$ will correct the threat of sorting, storing, locating large data by using new protocols. (O4,T7) strategy will try to influence threat of rejecting technology adoption by using real-time learning improvements based on the learner demand.

\section{B. Aggresive Strategies}

Aggressive strategies are identified when evaluating strength with opportunity $(\mathrm{S}, \mathrm{O})$. Authors identified four aggressive strategies which are shown in Table 8.

TABLE VIII. AGGRESSIVE STRATEGIES

\begin{tabular}{|c|}
\hline $\begin{array}{c}\text { Aggressive } \\
(\mathrm{S}, \mathrm{O})\end{array}$ \\
\hline$(\mathrm{S} 2, \mathrm{O} 1)$ \\
\hline$(\mathrm{S} 6, \mathrm{O} 4)$ \\
\hline$(\mathrm{S} 4, \mathrm{O} 5)$ \\
\hline$(\mathrm{S} 1, \mathrm{O} 2)$ \\
\hline
\end{tabular}

First aggressive strategy identified is (S2,O1). By combining the power of worldwide information access, safety information delivery and the power of media distribution in all segments mobile learning will increase its user base. Mobile learning can be adjusted to learner's profile in real-time leveraging modern technology (S6,O4). Implementing modular and portable mobile learning environment on a open platform will provide a way into currently close, complex architecture so that new features can be implemented by users if they want to $(\mathrm{S} 4, \mathrm{O} 5)$. Every user has its own independent way of learning but providing complete user experience on a intuitive platform will result in higher satisfaction $(\mathrm{S} 1, \mathrm{O} 2)$.

\section{Defensive Strategies}

Defensive strategies are identified when evaluating either weaknesses or threats (W or T). Threat number eight (T8), depletion of face to face interaction, is classified as such strategy as this is a field that has yet to be adequately explored and investigated.

\section{Remaining obstacles}

Remaining obstacles are identified when evaluating either weaknesses or threats (W or T) but it's necessary to not mix them with defensive strategies. Weakness number six (W6), unchartered industry is identified as the only remaining obstacle that can't be corrected or influenced on.

\section{Strategies, Activities AND goals}

The last step is to provide short but clear strategy description based on previously explained corrective, aggressive, defensive strategies and obstacles. Only then activities that will help facilitate implementation of recognized strategies can be defined. To measure the activities goals must be defined as a measuring instrument as shown in Table 9.

\begin{tabular}{|c|c|c|c|}
\hline \multicolumn{4}{|c|}{ Strategies - Activities - Goals } \\
\hline Strategy & $\begin{array}{l}\text { Strategy } \\
\text { description }\end{array}$ & Activity & $\begin{array}{l}\text { Goal } \\
\text { Description }\end{array}$ \\
\hline (S6,W3) & $\begin{array}{l}\text { Adapt to } \\
\text { user needs }\end{array}$ & $\begin{array}{l}\text { Provide a } \\
\text { survey of user } \\
\text { satisfaction }\end{array}$ & $\begin{array}{l}\text { Keep user } \\
\text { motivated }\end{array}$ \\
\hline$(\mathrm{O} 3, \mathrm{~T} 5)$ & $\begin{array}{l}\text { Organize } \\
\text { provided } \\
\text { content } \\
\text { seamlessly }\end{array}$ & $\begin{array}{l}\text { Research and } \\
\text { track user } \\
\text { behavior, } \\
\text { gestures }\end{array}$ & $\begin{array}{l}\text { Minimal time } \\
\text { focused on } \\
\text { actual device } \\
\text { usage }\end{array}$ \\
\hline$(\mathrm{O} 2, \mathrm{~T} 4)$ & $\begin{array}{l}\text { Reduce } \\
\text { heavy } \\
\text { technology } \\
\text { usage }\end{array}$ & $\begin{array}{l}\text { Provide short } \\
\text { breaks, } \\
\text { homework } \\
\text { assignments }\end{array}$ & $\begin{array}{l}\text { Don't let the } \\
\text { user to always } \\
\text { be in front of } \\
\text { the mobile } \\
\text { device }\end{array}$ \\
\hline$(\mathrm{O} 5, \mathrm{~T} 6)$ & $\begin{array}{l}\text { Implement } \\
\text { security } \\
\text { mechanisms }\end{array}$ & $\begin{array}{l}\text { Find bugs, } \\
\text { security holes, } \\
\text { vulnerabilities }\end{array}$ & $\begin{array}{l}\text { Fight against } \\
\text { cheaters }\end{array}$ \\
\hline
\end{tabular}




\begin{tabular}{|c|c|c|c|}
\hline$(\mathrm{S} 6, \mathrm{~T} 7)$ & $\begin{array}{l}\text { Migrate } \\
\text { users to new } \\
\text { environment }\end{array}$ & $\begin{array}{l}\text { Organize } \\
\text { training } \\
\text { sessions }\end{array}$ & $\begin{array}{l}\text { Convince user } \\
\text { that adaptation } \\
\text { is easy }\end{array}$ \\
\hline$(\mathrm{O} 6, \mathrm{~T} 2)$ & $\begin{array}{l}\text { Data } \\
\text { processing }\end{array}$ & $\begin{array}{l}\text { Leverage new } \\
\text { protocols and } \\
\text { techniques }\end{array}$ & $\begin{array}{l}\text { Provide fast } \\
\text { and accurate } \\
\text { search engine }\end{array}$ \\
\hline$(\mathrm{O} 4, \mathrm{~T} 7)$ & $\begin{array}{l}\text { Update } \\
\text { learning } \\
\text { material }\end{array}$ & $\begin{array}{l}\text { Listen to user } \\
\text { demands }\end{array}$ & $\begin{array}{l}\text { Have the best } \\
\text { content } \\
\text { tailored to } \\
\text { user needs }\end{array}$ \\
\hline$(\mathrm{O} 3, \mathrm{~T} 5)$ & $\begin{array}{l}\text { Content } \\
\text { management }\end{array}$ & $\begin{array}{l}\text { Implement } \\
\text { content } \\
\text { management } \\
\text { system }\end{array}$ & $\begin{array}{l}\text { User can } \\
\text { create, update } \\
\text { and delete his } \\
\text { resources }\end{array}$ \\
\hline$(\mathrm{S} 2, \mathrm{O} 1)$ & $\begin{array}{l}\text { Help users } \\
\text { figure the } \\
\text { benefits of } \\
\text { mobile } \\
\text { learning }\end{array}$ & $\begin{array}{l}\text { Advertise } \\
\text { mobile } \\
\text { learning }\end{array}$ & $\begin{array}{l}\text { Increase the } \\
\text { number of } \\
\text { users }\end{array}$ \\
\hline$(\mathrm{S} 6, \mathrm{O} 4)$ & $\begin{array}{l}\text { Organize } \\
\text { user } \\
\text { materials } \\
\text { based on the } \\
\text { active profile }\end{array}$ & $\begin{array}{l}\text { Provide } \\
\text { multiple } \\
\text { learning } \\
\text { profiles }\end{array}$ & $\begin{array}{l}\text { Profile } \\
\text { management }\end{array}$ \\
\hline$(\mathrm{S} 4, \mathrm{O} 5)$ & $\begin{array}{l}\text { Leverage } \\
\text { platform }\end{array}$ & $\begin{array}{l}\text { Implement } \\
\text { new features }\end{array}$ & $\begin{array}{l}\text { Keep user } \\
\text { satisfied }\end{array}$ \\
\hline$(\mathrm{S} 1, \mathrm{O} 2)$ & $\begin{array}{l}\text { Better } \\
\text { performance }\end{array}$ & Adapt to user & $\begin{array}{l}\text { Fulfill user } \\
\text { expectations }\end{array}$ \\
\hline $\mathrm{T} 8$ & $\begin{array}{l}\text { Invest in } \\
\text { new } \\
\text { technology } \\
\text { and } \\
\text { innovation }\end{array}$ & $\begin{array}{l}\text { Implement } \\
\text { two way } \\
\text { synchronous } \\
\text { lessons }\end{array}$ & $\begin{array}{l}\text { Let users } \\
\text { communicate } \\
\text { trough video }\end{array}$ \\
\hline W6 & $\begin{array}{l}\text { Finance } \\
\text { more } \\
\text { researches }\end{array}$ & $\begin{array}{l}\text { Research and } \\
\text { discover new } \\
\text { opportunities }\end{array}$ & $\begin{array}{l}\text { Know the } \\
\text { industry better }\end{array}$ \\
\hline
\end{tabular}

\section{CONCLUSION}

Since mobile learning is spreading rapidly and likely to become one of the most efficient ways of delivering higher education instruction in the future, it has become necessary to examine its implication for the design of teaching and learning. Learning is becoming more distributed where learners will use mobile devices to access information and learning materials from anywhere and at anytime. A young learner today will use search engines on the internet to find information rather than go to a library or ask a teacher. We are seeing a shift to learner centered education in which mobile devices will play a significant role. There is no doubt that the development and adoption of mobile technology continues to impact our society and education. In this article, authors have tried to take into account the specificities of m-learning using SWOT analysis in order to propose conceptual framework for defining strategies that will help in the process of adopting $\mathrm{m}$ learning which make a valuable contribution for the future research in this area.

\section{REFERENCES}

[1] E. Alepis, M. Virvou, K. Kabassi: „Mobile Education: Towards affective bi-modal interaction for adaptivity“, 2008

[2] G. Liu, Z. Jiao: „The Design of Mobile Learning System for Teachers' Further Education", Second International Workshop on Education Technology and Computer Science, 2010

[3] H. Weihrich, „The TOWS Matrix ---A Tool for Situational Analysis,“ Long Range Planning

[4] J. Waycott, A. Kukulska-Hulme: „Students' experiences with PDAs for reading course materials“, Personal Ubiquitous Computing, vol. 7, pp. 30-43, 2003

[5] R. Picek, M. Grčić, "Evaluation of the Potential Use of m-learning in Higher Education," ITI 2013 Proceedings "in press".

[6] S. Kurkovsky: „Integrating Mobile Culture into Computing Education“, IEEE, 2012

[7] W. Junfeng: „Mobile Learning-A New Type of Distance Education“, 2010

[8] ISO 10015:1999 Standard: Quality Management - Guidelines for Training, ISO Office Geneva, 1999

[9] R. Felton, “A question of SWOT," Metal Powder Report, vol. 59, no. 7, pp. 3, 2004

[10] El-Hussein, M. O. M., \& Cronje, J. C. (2010). Defining Mobile Learning in the Higher Education Landscape. Educational Technology \& Society, 13 (3), 12-21.

[11] Jones, R. Physical ergonomic and mental workload factors of mobile learning affecting performance of adult distance learner's student perspective, Orlando, 2009

\section{Creative Commons Attribution License 4.0 (Attribution 4.0 International, CC BY 4.0)}

This article is published under the terms of the Creative Commons Attribution License 4.0

https://creativecommons.org/licenses/by/4.0/deed.en_US 